\title{
The relationship of self-compassion and rumination in prediction of chronic depression
}

\author{
Samad Khoramniya ${ }^{1}$, Ali Akbar Foroughi ${ }^{2}$, Golfam Goodarzi ${ }^{1}$, Mehrdad Bahari Babadi ${ }^{3}$, Amir \\ Abbas Tahe ri ${ }^{1}$
}

1-MSc in Clinical Psychology, Department of Clinical Psychology, Kermanshah University of Medical Science, Kermanshah, Iran.

2- Assistant Professor, Department of Clinical Psychology, Kermanshah University of Medical Science, Kermanshah, Iran (Corresponding Author). $\quad$ E-mail: foroughi_2002@g mail.com

3- Master of Psychology, Department of Psychology, Lorestan University, Lorestan, Iran.

Received: 04/09/2020

Acce pted: 28/10/2020

\begin{abstract}
Introduction: Depression is a common disorder that is associated with negative emotional states. In recent years, the main emphasis has been on identifying risk factors and mechanisms involved in individual differences in vulnerability to depression.
\end{abstract}

Aim: The aim of this study is to investigate the role of self-compassion and rumination in predicting chronic depression.

Method: This study is a descriptive-analytical and cross-sectional study and the study population was people over 15 years old with a diagnosis of chronic depression who referred to the psychiatric clinic of Farabi Hospital in Kermanshah in 2017-2018. Sampling was a convenient method. A total of 360 people were evaluated, of which 300 were included in the study. Data were collected using Beck Depression Inventory (1961), Self-Compassion Questionnaire (2003) and Nolen-Hoxma and Murrow (1993) and Kolmogorov-Smirnov tests, Pearson correlation and multiple game regression analysis and SPSS 21 software were analyzed and reviewed.

Results: There is a negative and significant relationship between self-compassion (-0.490) and subscales of kindness to oneself (-0.482), human commonalities (-0.790) and mindfulness (0.457) with chronic depression, between the subscales of judgment There is a positive and significant relationship between self (0.511), isolation (0.542) and assimilation (0.550) with chronic depression. There is a positive and significant relationship between rumination (0.299) and subscales of ruminant responses (0.277) and distracting responses (0.315) with chronic depression.

Conclusion: Self-compassion and rumination are among the predictors of chro nic depression. As a result, chronic depression can be reduced by increasing self-compassion and reducing rumination.

Keywords : Self-compassion, Rumination, Chronic depression

How to cite this article : Khoramniya S, Foroughi AA, Goodarzi G, Bahari Babadi M, Taheri AA. The relationship of self-compassion and rumination in prediction of chronic depression. Shenakht Journal of Psychology and Psychiatry. 2020; 7 (5): 15-29 .URL: http://shenakht.muk.ac.ir/article-1-935-en.pdf

Copyright (C) 2018 the Author (s). Published by Kurdistan University of Medical Sciences. This is an open access article distributed under the terms of the Creative Commons Attribution-Non Commercial License 4.0 (CCBY-NC), where it is permissible to download, share, remix, transform, and buildup the work provided it is properly cited. The work cannot be used commercially without permission from the journal. 


\title{
بررسى نقش شفقت به خود و نشخوار ذهنى در بيشبينى افسردى مزمن
}

\author{
صمد خرم نيا'، على اكبر فروغى '، كلفام كودرزى'، مهرداد بهارى بابادى'، اميرعباس طاهرى' \\ ا. كارشناس ارشد روانشناسى بالينى، گروه روانشناسى بالينى، دانشكاه علوم بِ شكى كرمانشاه، كرمانشاه، ايران.
}

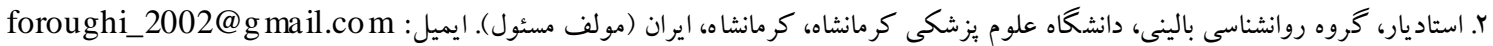

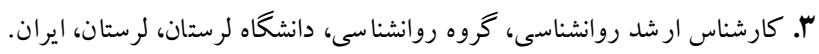

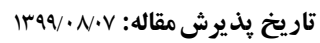

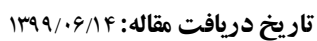

جكيده

مقدمه : افسردگى، اختلالى شايع است كه با حالات هيجانى منفى همر اه است. در سال هاى اخير، تأكيد عمده روى شناسايى عوامل

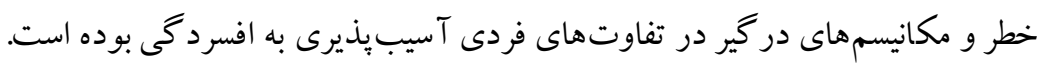
هدف: هدف اين بثزوهش، بر رسى نقش شفقت به خود و نشخوار ذهنى در ييشبينى افسردگى مزمن است. روش: اين مطالعه از نوع توصيفى -تحليلى و مقطعى بوده و جامعه يزوهش، افر اد بالاى ها سال، با تشخيص افسردگى مز من بودند كه

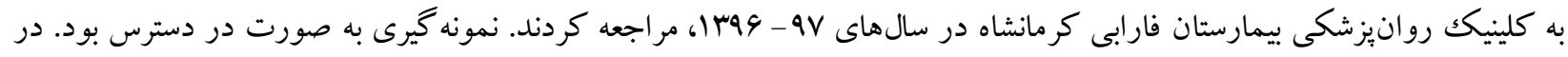

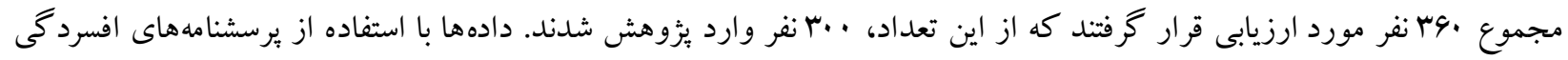

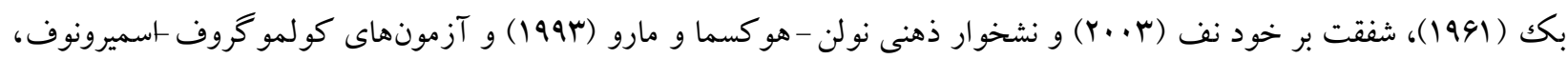

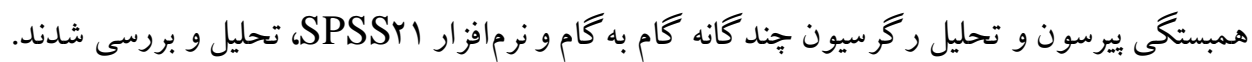

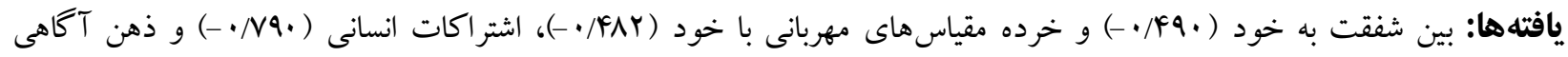

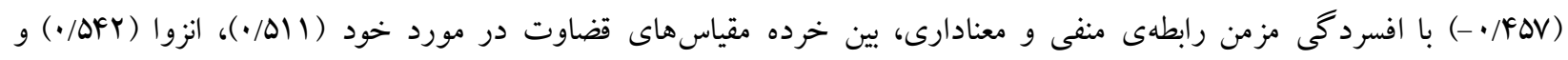

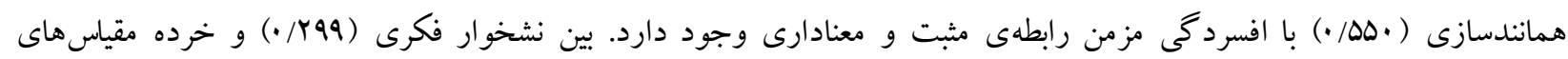

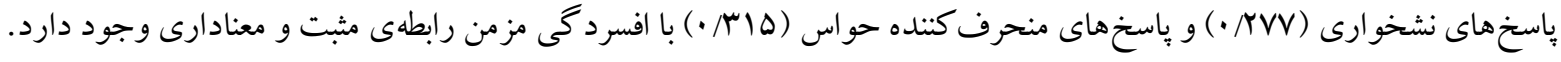
نتيجه كيرى: شفقت به خود و نشخوار فكرى از جمله يِيش يينى كنندهاى افسردگى مزمن مىباشند. در نتيجه با افز ايش شفقت به خود و كاهش نشخوار فكرى مى توان افسردگى مزمن را كاهش داد. كليدوازهها: شفقت به خود، نشخوار فكرى، افسردگى مز من 


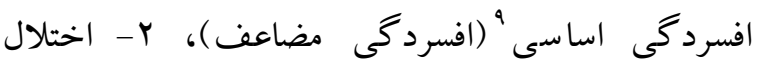

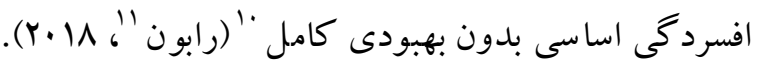
افسردگى به عنوان بيمارى سرما خورد گیى در ميان

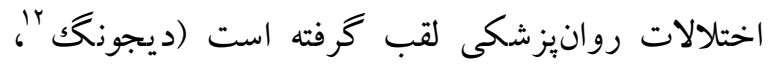

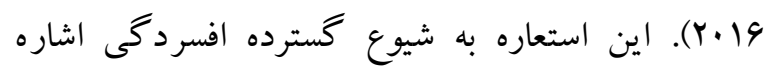
دارد. خلق افسرده و احساس عدم لذت، نشانههاى كليدى

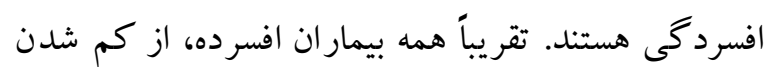
انرزى، شكايت دارند. هشتاد درصد از بيماران نيز از مشكلات خواب شكايت دارند. كاهش اشتها، عدم تمر كز، احساس بى ارزشى، بلا تصميمى، افكار مرتبط با مركى يا تمايلات خودكشى نيز شايع هستند (نوربالا،

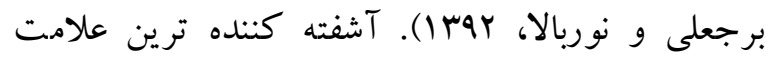
افسردگى كه به صورت بالقوه مهلكك ترين آنها نيز است،

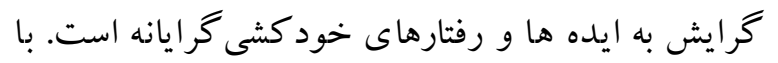

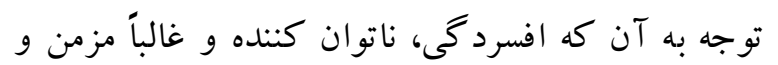
عود كننده است، شناخت عوامل خطرزا و مداخله

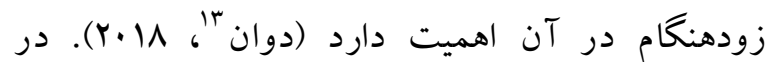
سالهاى اخير مطالعه الكوهاى تفكر در اختلالات افسردگى و بررسى افكار ناخواسته و نقش آن در دوام اختلالات هيجانى مورد توجه ئزوهشخران قرار كرفته

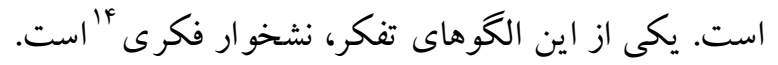

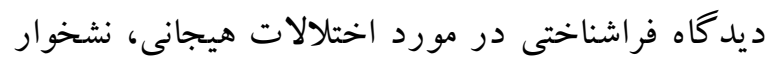
فكرى را از مؤلفههاى اصلى در شروع و تداوم افسردكى

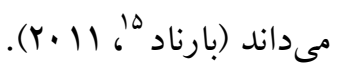
نشخوار فكرى عبارت است از فرايند تكرار شونده و غالباً اجتناب نايذير فكر كردن در مورد تجربه هاى كذشتهـ، كه

9 - Double depression

${ }^{10}$ - Major depressive disorder with poor interepisodic recovery

${ }^{11}$ - Rabon

${ }^{12}$ - DeJong

13 - Douven

14- Intellectual rumination

15 - Barnard
مقلمه

افسردگى'، اختلالى شايع است كه با حالات هيجانى منفى همراه است. در سالهاى اخير، تأكيد عمده روى

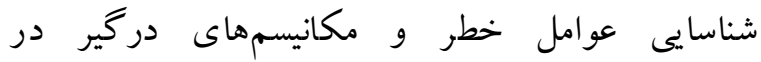
تفاوتهاى فردى آسيب يذيرى به افسردگى بوده است.

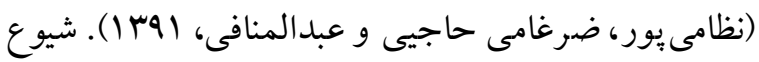
جهانى افسردگى و علائم آن در دهه هاى اخير افزايش يافته و بين ·r تا هY درصد در زنان و V تا Y I درصد در مردان گزارش شده است (ووس، آلن، آرورا، باربر، بو تا

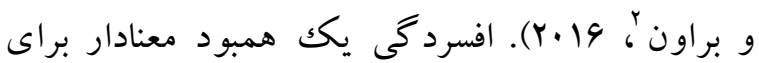
اختلالات روان يزشكى مز من محسوب مى شود و طيفى از ه تا ·س درصد همبودى با اختلالات بزشكى مختلف، براى اين اختلال مطرح شده است (ليم، تى، بِان و ليمّ

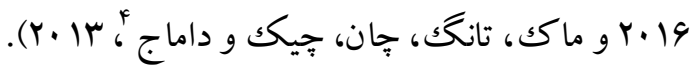
هر جند افسردگى تا حدود زيادى قابل درمان است؛ اما

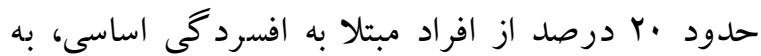

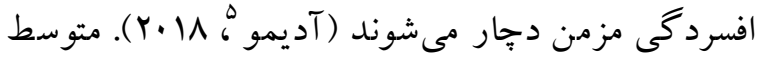

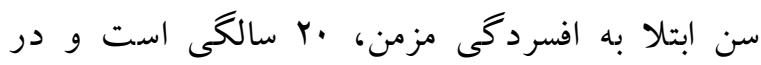
صورت اقدام به خود كشى و يا بسترى شدن بيشتر به

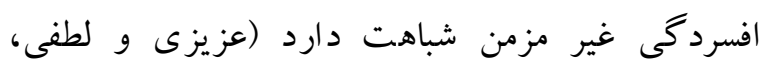

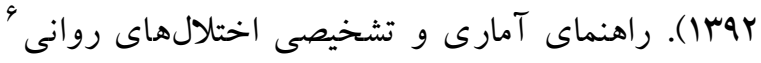
افسردگى مزمن را به دو شكل كلى تقسيم مى كند: 1 -

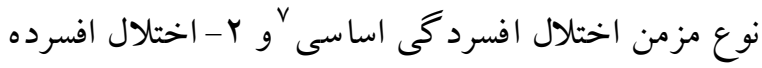
خويى ^. دو شكل فرعى تر آن نيز شناخته شده است كه عبارت از: ا- اختلال افسرده خويى به همراه اختلال

\footnotetext{
'- Depression

2- Vos, Allen, Arora, Barber, Bhutta \& Brown

${ }^{3}$ - Lim, Tee, Pan \& Lim

4- Mak, Tang, Chan, Cheak \& Damage

5 - Adamu

${ }^{6}$ - Diagnostic and statisticalmanual of mental disorders

7. Chronic major depressive disorder

${ }^{8}$ - Dysthymic disorder
} 
مىدهد و اين وضعيت باعث پايدارى افسردگى مى شود

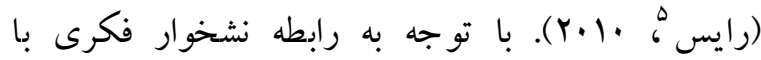

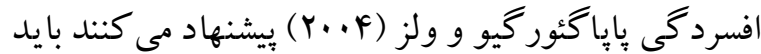
مقدمه درمان شناختى، درمان فراشناختى باشد و در آن باورهاى منفى و مثبت بيرامون نشخوار فكرى مورد جالش قرار گيرد، سبس از طريق آموزش توجه به بيمار آموزش داده مى شود تا نشخو ار فكرى را قطع كند و به

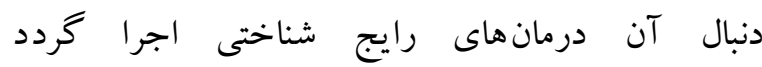

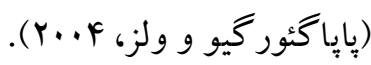
يكى ديخر از متغيرهايى كه در ارتباط با افسردگى مورد توجه قرار كرفته، شفقت به خود است. نف لو و داهم (Y) (Y)، شفقت بر خود را به عنوان يكك شيوه ياسخ دهى مطلوب به شكست ها و :بريشانىها توصيف كرد كه مهربانى معطوف به خود را به هنگام مواجهه با بريشانى

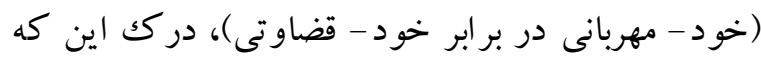
افراد در تجربه دشوارىها تنها نيستند تجربه مشترك بشىى در بر ابر انزواى ادراكك شده) و توجه و دقت به هر احساس بريشان كنندهاى بدون گم شدن در آن (ذهن آكاهى در برابر همانندسازى بيش از حد)، به عنوان مؤلفه هاى دو بخشى كه ارتباط درونى با هم دارند، در

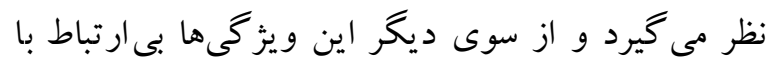
ويز گیى هاى شخصيت نمىتوانند باشند (نف و داهم،

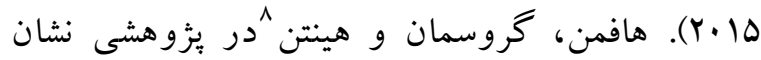
دادند كه توسعهى شفقت به خود به كاهش طيف وسيعى از مشكلات روانشناختى افراد از جمله افسردگى، اضطراب و استرس كمكك شايان تو جهى كرده است (هافمن و همكاران، II (Y). همجنين تحقيقات ديخرى

5- Raes

6. Compassion for yourself

7. Neff \& Dahm

8 - Hoffmann, Grossman \& Hinton
اغلب با افكار منفى در ر ابطه است و مانع از شيوههاى حل مسئله به شيوه ساز گار انه مى شود (بشارت و شهيدى،

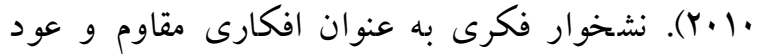
كننده تعريف مى شود كه گِرد يكك موضوع معمول دور مىزند. مطالعات بسيارى از رابطه تنگاتنگك بين افكار نشخوارى و انواع مختلف اختلالات هيجانى حكايت مى كند (نولن هو كسما، ماررو' و فريدريكسون '، 1999 ). 1999). با وجود اين، رابطه افكار نشخوارى با افسردگى نقطه شروع مهمى براى برداختن به مفهوم نشخوار فكرى

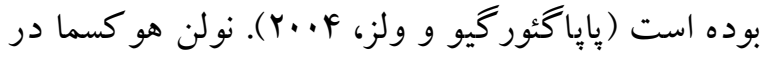
نظريه سبك هاى پياسخ (1999) به تبيين مفهوم نشخوار فكرى در افسردگى بِرداخته است. در نظريه سبككهاى

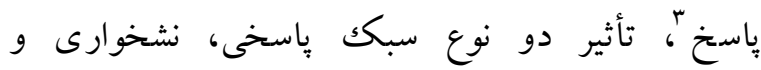
منحرف كننده حواس در خلق افسرده با يكديخر مقايسه

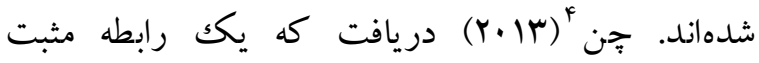
معنادارى بين نشخوار فكرى و افسردگى در افراد وجود دارد (آقايوسفى، خاربو و حاتمى، سهبا). وقتى فرد در نشخوار فكرى غرق مى شود، احساس مى كند كه دجار وضعيت غير قابل كنترل شده كه خطرناكك است؛ يعنى باورهاى منفى در مورد نشخوار فكرى به وجود مى آيد و منجر به افسرده شدن فرد مىشود. بر اساس اين مدل براى

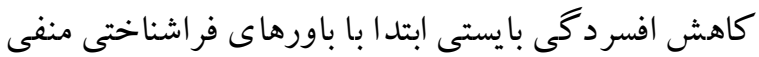
مثل غير قابل كنترل بودن نشخوار فكرى مقابل كرد و

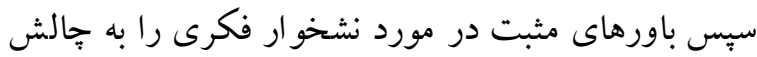
كشيد؛ زيرا توجه بيش از حد فرد به درون خود و فاصله كرفتن از بيرون موجب تكرار افكار منفى به خصوص درد در برد مورد كذشت مى شود و فرد را در حالت خلق منفى قرار

\footnotetext{
1- Morrow

2 - Fredrickson

3. Response Style Theory

4. Chena
} 
كه به كلينيك روانيز شكى بيمارستان فار ابى كرمانشاه در

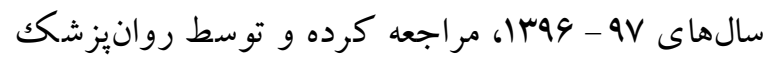
شناسايى شدند. در مجموع .4 نفر مورد ارزيابى قرار كرفتند كه از اين تعداد، ،9 نفر از آنها دجهار ريزش

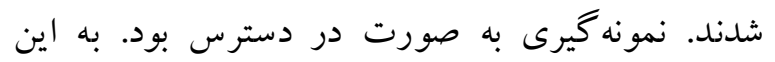

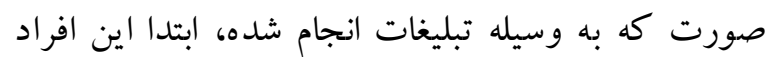

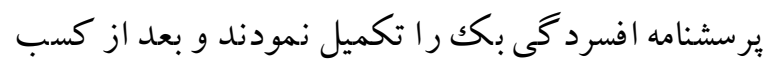
نمره در سطح افسرد گى متوسط به بالا (حداقل نمره •r) و انجام مصاحبه روانيزشكى توسط يكى از نويسندكان اصلى اين مقاله و دريافت تشخيص افسرد گى مزمن و دار ال بودن شرايط سنى بالاى ها لهال، اقدام به تكميل

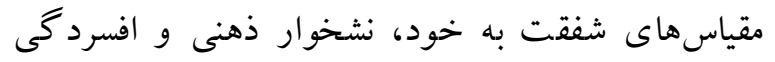
نمودند. شر كت در بيزوهش براى آزمودنى ها داوطلبانه و با رضايت آكاهانه بود و راهنمايىهاى لازم براى آنان هنگام تكميل بيرسشنامها، ارائه گُرديد. به منظور تحليل

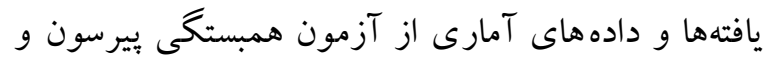
تحليل رگرسيون جند گانه گام به گام استفاده شد. به إنه

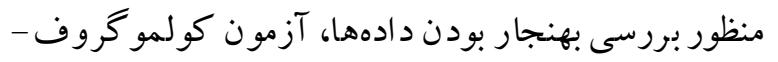
اسميرنوف انجام شد و مفروضهى بهنجارى دادهها تأييد

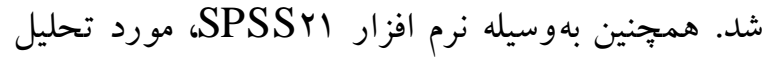
قرار گرفتند.

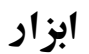

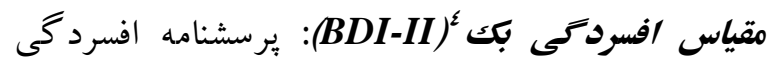

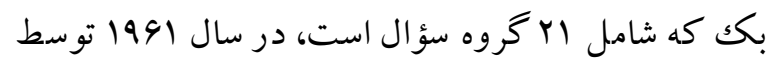
آرون بك،، بكو ارد، مندلسون، ماركى و ارباف ه تدوين شد. اين يرسشنامه شدت علائم افسردگى را مى سنجد. هر ماده (نشانه بيمارى) بر اساس شدت آن به جهار درجه

${ }^{4}$ - Beck depression inventory

5- Aaron Beck
نشان دادند كه شفقت به خود به طور مثبت با سلامت روان و ساز كارى روانشناختى رابطه دارد. به طور مثال سطوح بالاترى از شفقت به خود با رضايت بيشتر زندكى، يذيرش مشكلات، هوش هيجانى، ارتباط اجتماعى بهتر همر اه است و از سوى مقابل سطوح بايين آن با نشانهاى

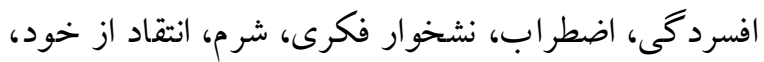
ترس از شكست همراه است (فرارى، ياب، اسكوت،

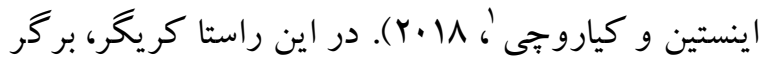

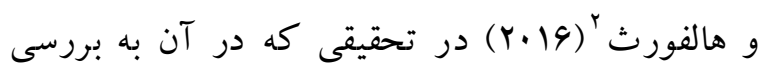
رابطه شفقت به خود و افسردگى برداختند، نشان دادند كه عدم شفقت ورزى فرد به خود مى تواند به عنوان يكك عامل آسيب بذيرى براى افسردگى عمل كند (كريخر و و

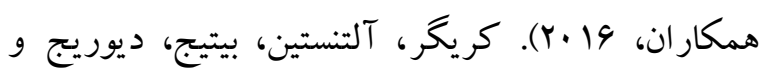

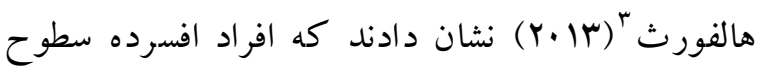
پايين ترى از شفقت به خود را نسبت به افراد غير افسرده

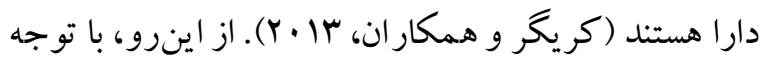
به آنجه كه كُته شد شناسايى متغيرهايى كه زمينهى بروز يا بيشخيرى از افسردگى را فراهم مىنمايد مى تواند نقش

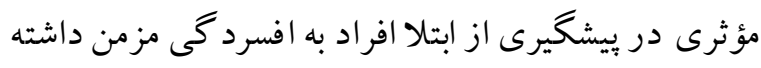
باشد. از اينرو با توجه به مطالعات انجام شده كمتر به

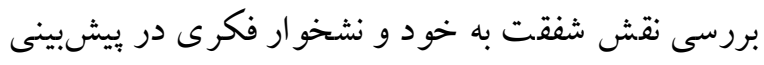
افسردگى مزمن برداخته است؛ بزّوهش حاضر، با هدف بررسى نقش شفقت به خود و نشخوار ذهنى در بيشبينى افسردگى مزمن انجام شد.

اين مطالعه از نوع توصيفى -تحليلى و مقطعى بوده و جامعه يزوهش، افراد با تشخيص افسردگى مزمن بودند

\footnotetext{
1 - Ferrari, Yap, Scott, Einstein \& Ciarrochi

2- Krieger, Berger \& Holtforth

${ }^{3}$ - Krieger, Alt enstein, Baettig, Doerig \& Holtforth
} 
زيرمقياسهاى مو فقيت و وابستخى و خود كنترلى، سه/ • و • • • و DV/ • حاصل شد. در مجموع بايايى و روايى اين مقياس در حد متوسط ارزيابى شد (برزگرى دهج و ولهائ

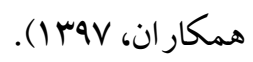
مقياس شفقت برخود "(SCS): اين مقياس يكك ابزار خود

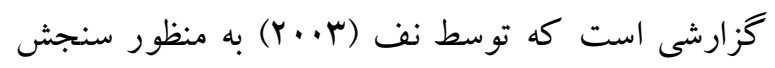
ميز ان خود شفقت ورزى ساخته شده است. اين مقياس كويه دارد و به منظور سنجش لم مؤ لفه دو بُعدى اين سازه يعنى خود مهربانى (ه گويه)/ خود - قضاوتى (ه گويه)، F) تجربه مشترك بشرى (F Fويه)، انزواى ادراكك شده

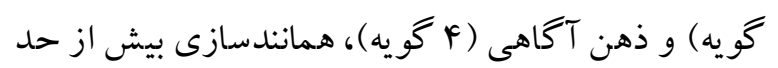

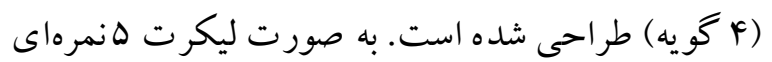

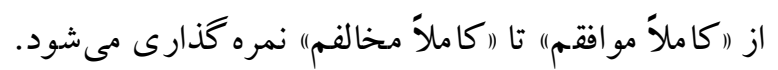
ميانكين نمر ات شش مؤلفه با هـم جمع شده و يك نمرهى كلى شفقت بر خود حاصل مىشود. خرده مقياسهاى

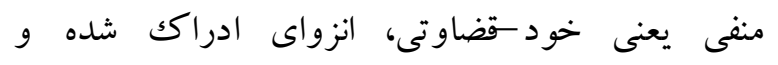
همانندسازى بيشازحد، بر عكس نمره كذارى مى شوند

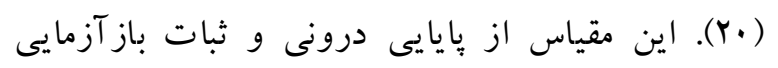
بالايى برخوردار بوده است (برى، كوالسكى، فرگوسن و

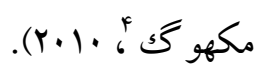

يزوهش انجام شده توسط نف (10 (Y)، بايايى و روايى بالايى را براى مقياس مذكور گز ارش نموده است. بايايى

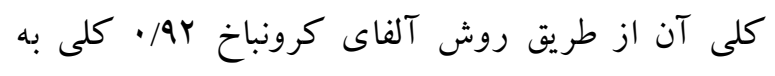
دست آمد. همجينين هر كدام از زير مقياسها نيز از همسانى درونى خوبى برخوردار بودند (از ND/ تا اN/•).

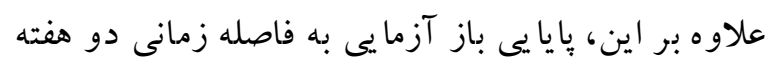

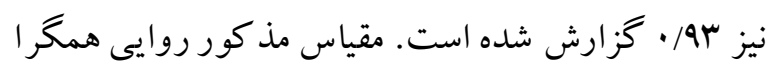

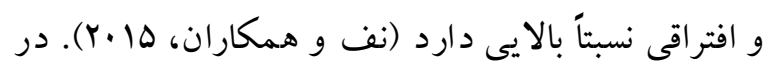

3 - Self-compassion

${ }^{4}$ - Berry, Kowalski, Ferguson \& McHugh
تقسيم شده و از صفر تا سه نمره مى گيرد. نمره صفر نشان دهنده بِائين ترين ميز ان و نمر ه ب نشان دهنده بالاترين ميز ان شدت تجربه يكك نشانه افسردگى است. جمع نمرات هر برسشنامه مى تو اند بين · تا سو باشد. اين برسشنامه قابل

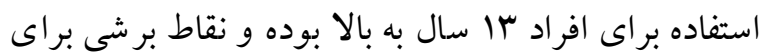

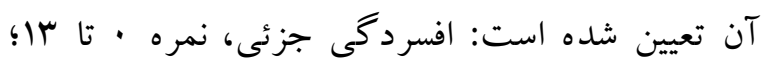

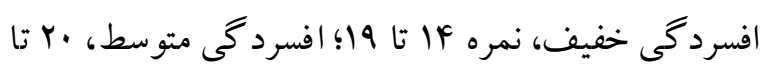

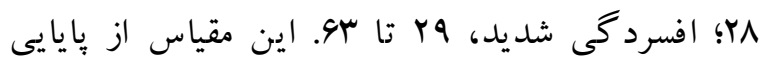
درونى و ثبات باز آزمايى بالايى برخوردار بوده است.

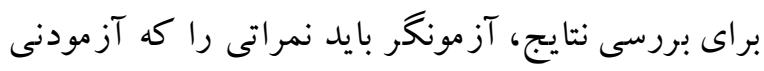

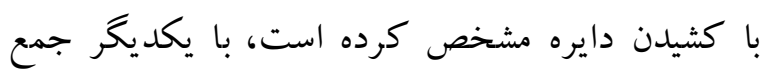
كند. بايد يادآور شد كه فقط يكك جمله از هر ماده كه بالاترين ارزش را دارد، مورد قبول در محاسبات است. جمع نمرات از · تا كو مىتو اند نوسان داشته باشد، نمره منفى منظور نمى گردد. اين درجات در تشخيص افسردگى بيشنهاد شده است (بكك، شاو، راش و وردى

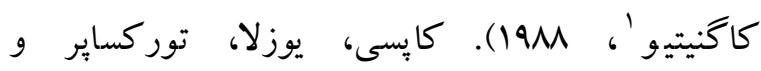

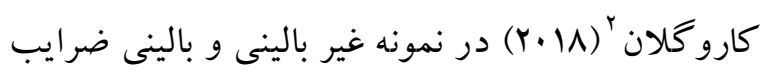

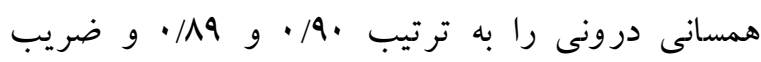
بازآمايى را در نمونه غير بالينى و بالينى به ترتيب AV/ • و بF

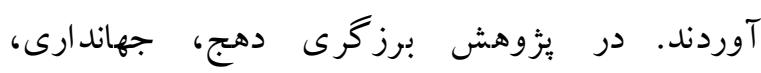
محموديور و نادرى (Ir (I) يايايى اين آزمون با استفاده از آلفاى كرونباخ VN٪ به دست آمد. براى بررسيروايى نيز ضريب همبستخى هر سؤ ال با نمره كل برسش نامه محاسبه

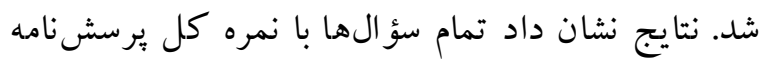

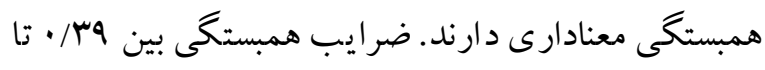

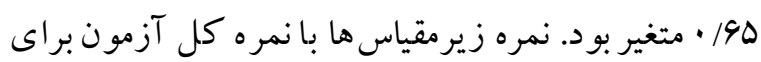

\footnotetext{
1- Beck, Shaw, Rush \& Cognitive

2- Kapci, Uslu, Turkcapar \& Karaoglan
} 
اين تحقيق ضريب آلفاى كرونباخ براى نمره كل شفقت به خود /9Fq/، مهربانى با خود MIN/ •، قضاوت در مورد

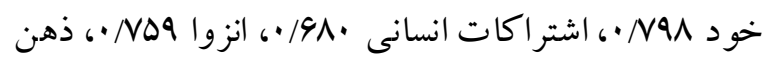

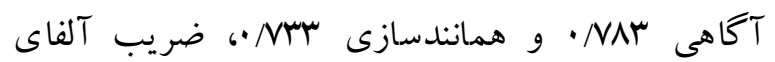

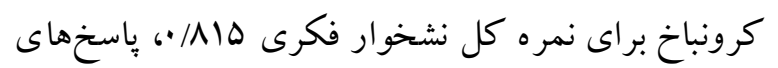

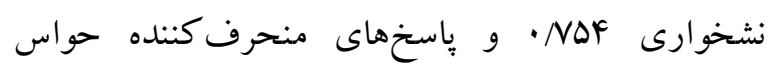

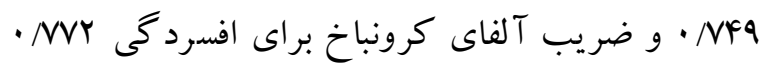

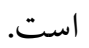

\section{يافته ها}

نتايج تحقيق نشان داد كه از بين اعضاى نمونه ه9/V٪ مرد و و F/ زن مى باشند.

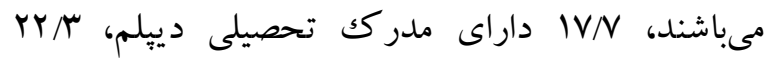
داراى مدر كك تحصيلى كاردانى، •/هr داراى مدركك تحصيلى كارشناسى و هاY\% داراى تحصيلات كارشناسى ارشد مىباشند. وضعيت سنى بِاسخكويان نشان داد كه

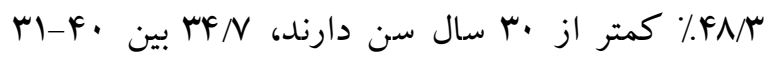

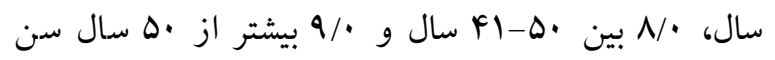
دارند. جدول ا ميانگين و انحراف استاندارد شفقت به خود، نشخوار فكرى و افسردگى مزمن را نشان مى دهد.
تحقيق مؤمنى، شهيدى، موتايى و حيدرى (IMYY) همسانى درونى مقياس خود شفقت ورزى برحسب ضريب آلفاى كرونباخ محاسبه شد و با ضر يب همبستكى • • مورد تأييد قرار گرفت. ضريب همبستخى معنادار

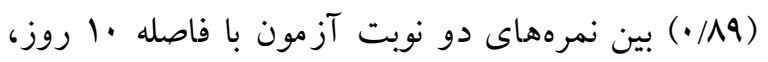
حاكى از بايايى بازآزمايى بالاى مقياس است (مؤمنى و

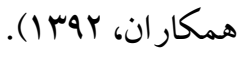
مقياس بإنخ نشخوار ذهنى '(RRS): اين مقياس توسط

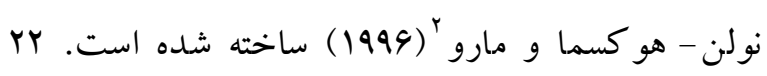
ماده دارد و به Y زيرمقياس باسخهاى نشخوارى و و ياسخهاى منحرف كننده حو اس، تقسيم مى شود (IV). در يك طيف ليكرت F درجهاى از (اهركز") تا (هميشه) قرار

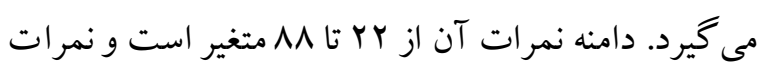
بالاتر با نشخو ار فكرى بالاتر همراه است. روايى و ويايايى اين برسشنامه در بُزوهشهاى مختلف نشان داده شده

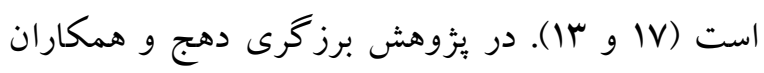
(IrqV) آزمون-باز آزمون به ترتيب /91/ و •V/ • به دست آمد. يزوهشهاى مختلف نشان مىدهد همبستگى باز آزمايى

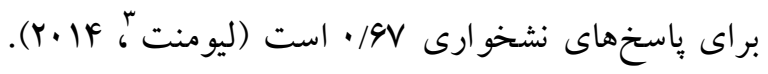
باقرى نزاد و همكار ان براى نخستين بار اين مقياس را ال

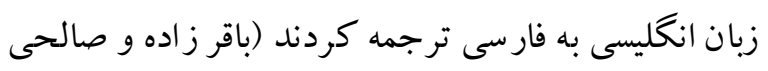

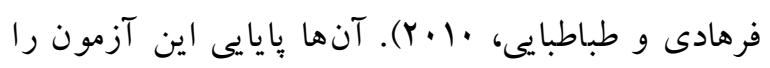

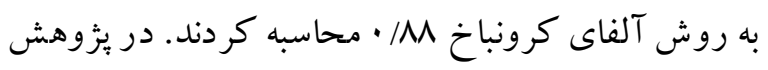
حاضر براى بررسى روايى، همبستكى هر سؤ ال با نمره

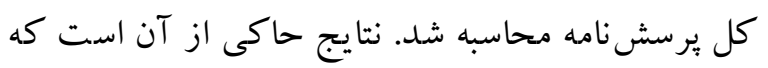
تمام سؤال ها با نمره كل برسشنامه همبستخى معنادارى

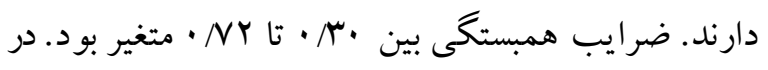

1 - Ruminative response scale

${ }^{2}$ - Nolen-Hoeksema \& Morrow

${ }^{3}$ - Luminet 


\begin{tabular}{|c|c|c|}
\hline انحر اف معيا ر & ميانكين & متغير \\
\hline$\Delta / 11$ & $10 / \cdot 1$ & مهربانى با خود \\
\hline$\Delta / T \Delta$ & $10 / 49$ & قضاوت در مورد خود \\
\hline$r / \cdot r$ & Ir/NG & اشتراكات انسانى \\
\hline$F / r \Delta$ & I D/ra & انزوا \\
\hline$F / F$ & $I T / M F$ & ذهن آكاهى \\
\hline$r / \cdot 1$ & $1 r / 99$ & همانندسازى \\
\hline rF/FA & $\Lambda \cdot / \cdot r$ & شفقت به خود \\
\hline$\Delta / \wedge$ & re/. & ياسخ هاى نشخوارى \\
\hline$\Delta / \cdot 9$ & $r \Delta / M V$ & هاسخ هاى منحرف كننده \\
\hline$\wedge / \wedge$. & ه D//D & نشخوار فكرى \\
\hline$\Lambda / \Delta r$ & $\Delta r / F Q$ & افسرد \\
\hline
\end{tabular}

نشخوار فكرى با افسردگى مزمن رابطه معنادارى وجو د دارد؛ و متغيرهاى شفقت بر خود و نشخوار فكرى مى توانند افزايش در ميزان افسردگى مزمن را بيشبينى كنند؟ قبل از استنباطهاى آمارى، به منظور برر سى بهنجار بودن دادهها، آزمون كولمو گروف - اسميرنوف انجام و مفروضهى بهنجارى دادها تأييد شد. جدول r ميزان همبستخى بين شفقت به خود و خرده مقياس هاى آن را با افسردگى مزمن را نشان مى دهد.
همان طور كه در جدول بالا مشاهده مىشود ميانگين و

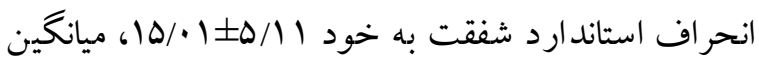
و انحراف استاندارد نشخوار فكرى . • .

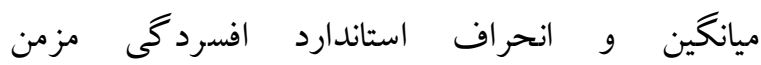
Dr/FG IN/Or دربارهى نقش شفقت به خود و نشخوار فكرى در بيشبينى افسردگى مزمن، از آزمون همبستخى بيرسون و

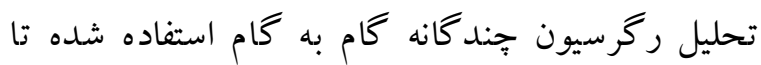
بدين سؤال ياسخ داده شود كه آيا بين شفقت بر خود و

\begin{tabular}{|c|c|c|}
\hline \multicolumn{2}{|c|}{ افسرد } & \multirow{2}{*}{ متغير } \\
\hline معنادارى & ضريب همبستكى & \\
\hline.$/ . r$ & $-\cdot /$ ANr & مهر بانى با خود \\
\hline$\cdot / \cdot 1$ &.$/ 011$ & قضاوت در مورد خود \\
\hline$\cdot / . r$ & $-\cdot / v a$ & اشتراكات انسانى \\
\hline.$/ . F$ & . /DFY & انزوا ان \\
\hline$\cdot \cdots$ & $-\cdot / F \Delta V$ & ذهن آكاهى \\
\hline$\cdot \cdots$ & $\cdot / \Delta \Delta$ & هماندسازى \\
\hline
\end{tabular}


بر خود با افسردگى رابطهى منفى و معنادارى وجود دارد و ضريب همبستخى بين شفقت بر خود با افسرد گى مزمن

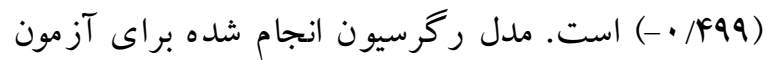
فرضيه اول يُزوهش، يُك مجموعه از بيشبينى كنندهها را در يكك كام شامل شد. نتايج اين آزمون در جدول بـ قابل مشاهده است. جدول r ضرايب حاصل از تحليل رگرسيون گام به گام افسردگى مزمن بر حسب ابعاد متغير شفقت بر خود را نشان مى هد.
همان طور كه در جدول Y مشاهده مى شود بين شفقت بر خود و ابعاد آن با افسردگى مزمن رابطهى معنادارى وجود دارد. بدين صورت كه از بين خرده مقياسهاى شفقت به خود، مهربانى با خود (r=-•rAY)، اشتراكات

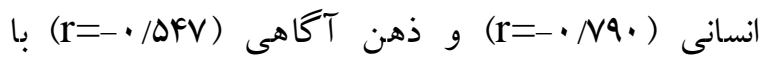
افسردگى مزمن رابطهى منفى و معنادارى وجود دارد و بين خرده مقياس هاى قضاوت در مورد خود (r=11 (r=1)،

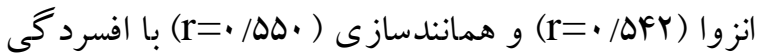
مزمن رابطهى مثبت و معنادارى وجود دارد. بين شفقت

\begin{tabular}{|c|c|c|c|c|c|c|c|}
\hline معنادارى سطح & & استاندارد خطاى & ضريب بتا & B & & متغير ها & كامها \\
\hline$\cdot / \cdots$ & $-Y / Y \wedge \Lambda$ & $-\cdot /|r|$ & $\cdot|| r \mid$ & $-\cdot / \mathrm{YVA}$ & $\cdot / \mathrm{IV}$ & اشتراكات انسانى & 1 \\
\hline
\end{tabular}

همانطور كه جدول r نشان مىدهد متغير اشتراكات تغييرات در واريانس افسردگى مزمن را محاسبه كرد.

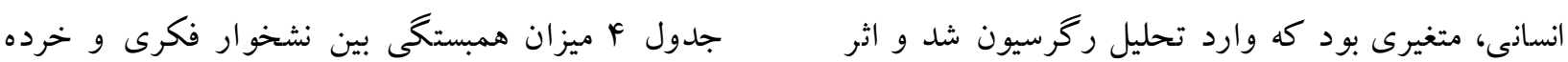

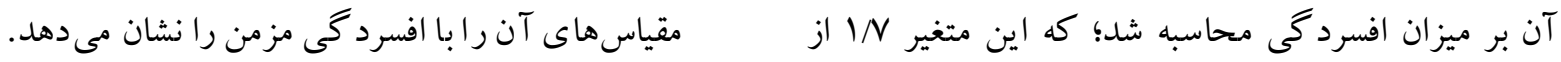

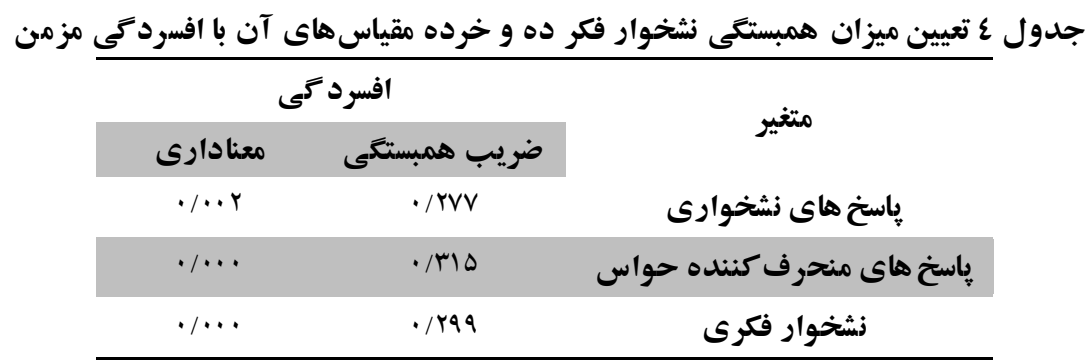

وجود دارد. جدول ها ضرايب حاصل از تحليل ركرسيون كام بهام افسردگى مزمن برحسب ابعاد متغير نشخوار فكرى را نشان مىدهد.
همانطور كه در جدول F مشاهده مى شود بين نشخوار فكرى (r=/r99) و خرده مقياس هاى آن يعنى باسخهاى نشخوارى (r=./TVV) و ياسخهاى منحرف كننده حواس (r= با افسردگى مزمن رابطهى مثبت و معنادارى ) 
جدول 0 ضر ايب حاصل از تحليل رگرسيون كام به كام افسردكى مزمن برحسب ابعاد متغير نشخوار فكرى

\begin{tabular}{|c|c|c|c|c|c|c|c|}
\hline سطح معنادارى & $\mathbf{t}$ & خطاى استاندارد & ضريب بتا & B & & متغير ها & كام ها \\
\hline$\cdot / \cdots$ & $\Delta / V Y F$ & $\cdot / \mu 1 \Delta$ & $.1 .9 r$ & $\cdot / \Delta Y V$ & .1 .99 & קاسخ هاى منحرف كننده & 1 \\
\hline
\end{tabular}

افسردگگ مزمن را بيشبينى مى كند. جدول 9 بيش بينى

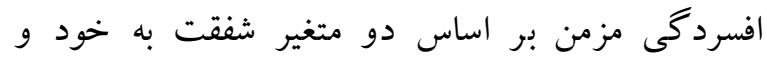
نشخوار فكرى را نشان مىدهد.
جدول ه نتايج تحليل رگرسيون گام به گام در مورد قدرت بيشبينى افسردگى توسط خرده مقياسهاى نشخوار فكرى رانشان مىدهد كه از بين اين دو خرده مقياس ياسخ هاى منحرف كننده حواس به تنهايى 9/9

جدول 7 ضر ايب حاصل از تحليل ركرسيون كام به كام افسردكى مزمن بر حسب شفقت به خود و نشخوار فكرى

\begin{tabular}{|c|c|c|c|c|c|c|c|}
\hline سطح معنادارى & $\mathrm{t}$ & خطاى استاندارد & ضريب بتا & B & & متغير ها & كامها \\
\hline$\cdot / \ldots$ & $\Delta / F \cdot r$ &.$/ . \Delta F$ & . / Y99 & - / rq. & $\cdot 1 \cdot 19$ & نشخوار فكرى & 1 \\
\hline
\end{tabular}

شفقت به خود، مهربانى با خود، اشتراكات انسانى و ذهن آكاهى با افسردگى رابطهى منفى و معنادارى وجود دارد و بين خرده مقياسهاى قضاوت در مورد خود، انزوا و همانندسازى با افسردگى رابطهى مثبت و معنادارى وجود دارد. بين شفقت به خود با افسردگى رابطهى منفى و و معنادارى وجود دارد و اين بدان معنى است كه شفقت به خود و خرده مقياسهاى مهربانى با خود، اشتراكات انسانى و ذهن آكاهى باعث كاهش افسردگى مى شوند و و خرده مقياسهاى قضاوت در مورد خود، انزوا و همانند سازى باعث افزايش افسردگى مىشوند. يافتههاى ئزوهش حاضر با نتايج يزوهشهاى كريخر و همكاران

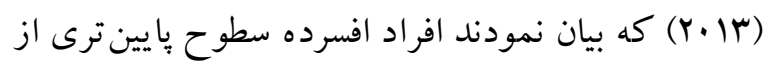
شفقت به خود را نسبت به افراد غير افسرده دار ا هستند (كريخر و همكاران، سا.Y)، كريخر، بركر و هالفورث (Y.19) كه نشان دادند عدم شفقت ورزى فرد به خود مى تو اند به عنوان يكك عامل آسيبذيذيرى براى افسرد
جدول 4 نتايج تحليل رگرسيون گام به گام در مورد قدرت بيشبينى افسردگى توسط دو متغير شفقت به خود و نشخوار فكرى رانشان مىدهد رانشان مىدهد كه از بين اين دو متغير نشخوار فكرى به تنهايى 1/9 افسردكى مزمن را بيش بينى مى كند. هدف عمده مطالعه حاضر، برر سى نقش شفقت بر خود و نشخوار فكرى در بيشبينى افسردگى در يكك نمونه افراد با تشخيص افسردكى مزمن بودند كه به كلينيك روانيزشكى بيمارستان فارابى كرمانشاه در سالهاى وها1، مراجعه مى كردند، بود. اولين فرضيه بثزوهش اين بود كه شفقت به خود و خرده مقياس هاى آن يعنى بين مهربانى با خود؛ قضاوت در مورد خود؛ اشتراكات انسانى؛ انزوا؛ ذهن آكاهى و همانندسازى با افسردگى بـى ارتباط معنادارى وجود دارد. نتايج اين يزٔوهش فرضيه اول را تأييد كرد. به طورى كه از بين خرده مقياسهاى 
نسبت به تجارب ناخوشايند افزايش يابد. به علاوه مؤلفهاى خود شفتتى با ايجاد كسلش شناختى باعث مىشود كه فرد به جاى يكسان دانستن خود با افكار تكرار شونده، بدون هر گونه قضاوت به مشاهده آنها بيردازد و از درگير شدن و كنترل آنها يرهيز كند.

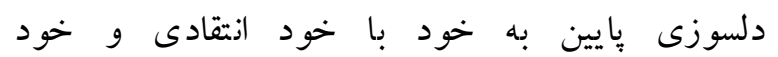

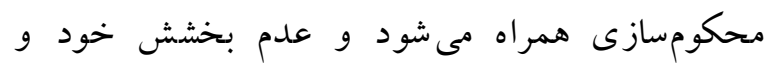
ديخران نيز منجر به نشخوار گرى ذهنى شده، علائم افسردگى را تداعى مى كند. از بسيارى جهات شفقت به به له خود مى تو اند يكى راهبرد مقابلهاى هيجانمحور مفيد در

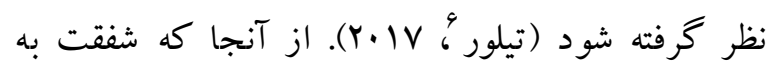
خود، نيازمند آكاهى به هشيار انه از هيجانات خود است ديخر از احساسات دردناك و ناراحت كننده اجتناب نمى شود؛ بلكه با مهربانى، فهم و احساس اشتراكات

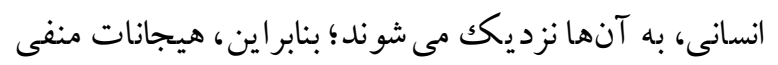
به حالت احساسى مثبت ترى تبديل مىشوند و به فرد افسرده فرصت دركك دقيقتر شرايط و انتخاب كارهاى مؤثر براى تغيير خود يا شرايط را، به صورتى اثربخش و مناسب مىدهند. همجنين شفقت به خود به فعالسازى

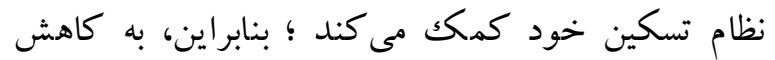
اجتناب از هيجانات منفى در افراد منجر مى شود

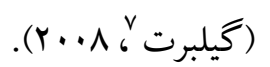

دومين فرضيه بثزوهش اين بود كه بين نشخوار فكرى و خرده مقياسهاى آن يعنى باسخهاى نشخوارى و و باسخهاى منحرف كننده حواس با افسردگى ارتباط معنادارى وجود دارد. نتايج اين يزوهش فرضيه دوم را تأييد كرد. به طورى كه بين نشخوار فكرى و خرده مقياسهاى آن يعنى ياسخهاى منحرف كننده حواس و

6- Taylor

7. Gilbert
عمل كند (كريخر و همكار ان، 19.r)، نف 'و همكاران كه نشان دادن شفقت به خود بالاتر بيشبينى (Y)

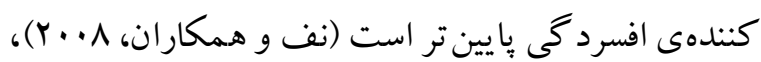

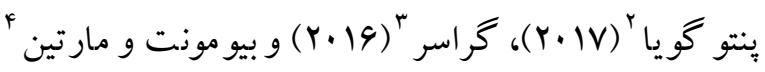
(Y.10) كه نشان دادند شفقت ورزى به خود موجب كاهش افسردگى مى گردد همسو و هم راستا است

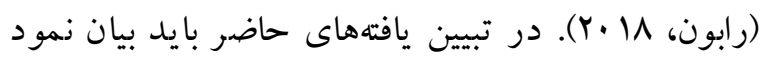
شفقت به خود از طريق ايجاد مراقبت، توجه جدى به خود و بيشنهاد فرايندهاى درونى دلسوزانه به تغيير افراد كمكك مى كند. اين تغييرات مى تواند به صورت نوعى از درمان فيزيولوزى - روانى عصبى تعبير و تفسير شود

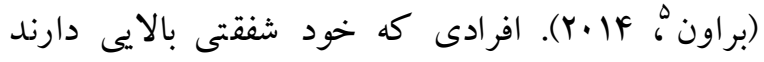
رنجهاى اجتناب نايذيرى كه كمابيش در همه افراد تجربه مىشود را به شيوههاى ناكارآمد خودمحكوميازى، احساس انزوا و همانندسازى افراطى با افكار و هيجانهاى منفى شدت نمى بخشند. همجِنين در شر ايط سخت روانى اين افراد به اين موضوع توجه دارند كه دجار خطا و اشتباه و حتى شكست مى شوند. اين آكاهى باعث مى شود كه بيذيرند فعاليتهايشان الزاماً كامل نيست؛ در نهايت اين دركك احساس مشتركك بين انسانها از منزوى شدن آنها جلو گيرى مى كند و بيوندهاى اجتماعى آنها را را كسترش مى دهد كه اين به نوبه خود باءث تسكين خلق منفى و افسردگ مى مى شود. ذهن آكاهى كه خود، متمر كز كردن تو جه در زمان حال و مشاهده يذيرش افكار و احساسات بدون قضاوت را شامل مى شود يكى از مؤلفهاى اصلى خود شفقتى به شمار مىرود كه سبب مى شود يذيرش و گشود گى افراد

\footnotetext{
1. Neff

2 - Pento goya

3. Grasser

4- Biomonet \& Martin

5 - Brown
} 
فرضيه مىتوان كفت وقتى فرد در نشخوار فكرى غرق

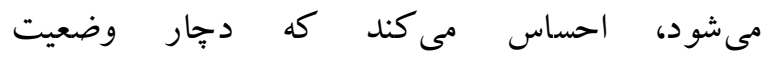
غيرقابل كنترلى شده كه خطرناكك است، يعنى باورهاى

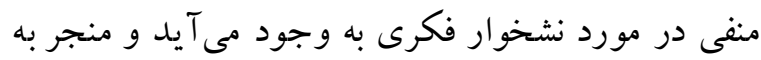
افسرده شدن فرد مىشود. در اينجا فرد در رويارويى با رويدادهاى منفى و رايج زندگىى، به جاى تعديل كردن

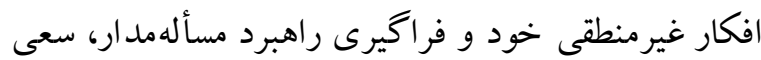
مى كند به بيامدهاى باورها و نگرشهاى ناكار آمد خود متمر كز شود. در اين صورت يا بر خود متمركز مى شود (فكر مى كند كه جرا مشكلاتى دارد كه ديخران ندارند، يا جرا نمى تو اند بهتر به ادارهكردن امور ببردازد)، يا بر علائم منفى خُلق خود متمركز مى شود (فكر مى كند

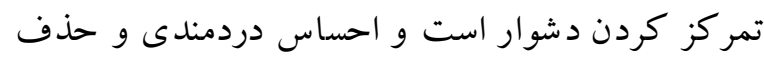
ناتوانى مى كند) و يا بر علل و بيامدهاى احتمالى خُلق منفى متمركز مىشود (فكر مى كند اكر در همين حالت باقى بماند، نمى تواند وظايفش را انجام دهد). حذف سف اينها موجب انزواى بيشتر فرد، انتقاد از خود، مرور احساسات ناشى از مشكل، نگُ انى درباره حل نشدن مشكل، كاهش قدرت ساز كارى، تجربه استرس بيشتر و از دست دادن انخيزه عمل و توانايى حل مسئله شده و در سر نتيجه فرد دجار افسردگى مى شود.

\section{نتيجه كيرى}

نتايج اين مطالعه بيانگر نقش شفقت به خود و نشخوار ذهنى در بيشبينى افسردگى مزمن است. اين يافته مى تواند تبيين و سببشناسى نشانهاى افسردگى را با توجه به متغيرهاى آسيبڤيذيرى شناختى تسهيل كند؛ مانند ساير يزوهش ها اين يزوهش نيز خالى از محدوديت

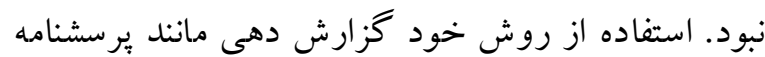
ممكن است با سو گيرى همراه باشد و اطلاعات دقيقى
ياسخهاى نشخوارى رابطهى مثبت و معنادارى وجود دارد و اين بدين معنى است كه با افزايش نشخوار فكرى و

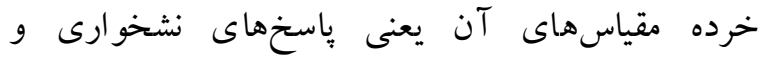
״اسخهاى منحرف كننده حواس افسردگى نيز افزايش

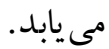
نشخوار فكرى توانست ميزان معنادارى از تغيير در افسردگى را بيشبينى كند. نتايج يزوهش، يافتهاى

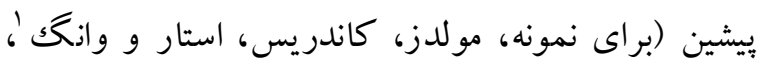

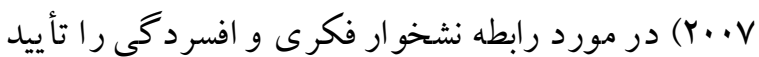

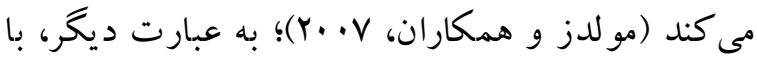
وجود تفاوتهاى فرهنگى و اجتماعى، نشخوار فكرى توانسته است، ميزان افسردگى را ييشبينى كند. بيش از

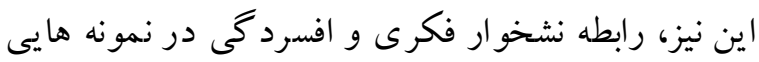
غير از جامعه آمريكا نيز نشان داده شده است. براى نمونه،

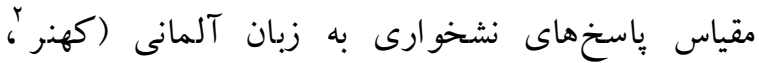

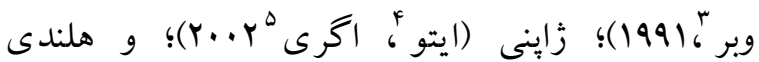

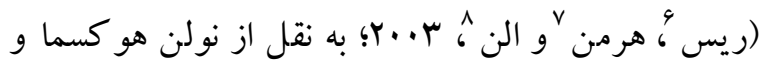

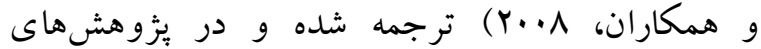
مختلف مورد استفاده قرار گرفت. نولن هو كسما، ويسكو

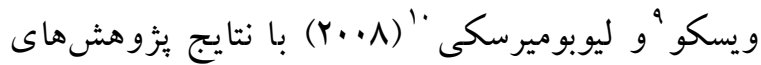
ييشين نشان مىدهند، با كنترل ساير متغيرهاى سهيم در افسردگى، افرادى كه از سبك بِاسخى نشخوارى استفاده مى كنند، بيشتر احتمال دارد در آينده، به يكك دوره بالينى افسردگى مبتلا شوند و اختلال افسردگى وخيمتر شود

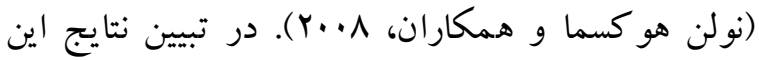

\footnotetext{
1- Moulds, Kandris, Starr \& Wong

- Kuehner

3. Weber

4 - Ito

5. Agari

6 - Raes

7. Hermans

8 - Eelen

9 - Wisco

${ }^{10}$ - Lyubomirsky
} 
Qomprovince, HealthPsychology, 14,.97-79. (InPersian)

Azizi A, MohammadkhaniP, LotfiS, BahramkhaniM. (2013). The validity and reliability of the Iranian version of the Self-Compassion Scale. Practice in Clinical Psychology, 1(3):149-55.

Bagherinezhad M, Salehi Fadradi J, Tabatabai M. (2010). The relationship between rumination and depression in a sample of Iranian students, Studies in Education \& Psychology, 11(1)2138. (InPersian)

Bamard LK, Curry JF. (2011). Self-compassion: Conceptualizations, correlates, \& interventions. Review of general psychology, 15(4):289.

Barzegari Dehj A, Jahandari P, Mahmoudpour A, Naderi R. (2018). The mediating role of selfcare in the relationship between rumination and depression in veterans with post-traumatic stress disorder, Nurse and Physician Quarterly In War, 19(6), 40-32. (InPersian)

Beck AT, Rush AJ, Shaw BF. (1988). Cognitive Therapy ofDepression, John Wiley \& Sons.

Beck AT. (1961). Beck depression inventory-II. San Antonio, 78(2), 490-8.

Berry KA, Kowalski KC, Ferguson J, McHugh TLF. (2010). An empirical phenomenology of young adult women exercisers' body self-compassion. Qualitative research in sport and exercise, 2(3), 293-312.

Besharat MA, Shahidi S. (2010). Perfectionism, anger, and anger rumination. International Journal of Psychology.

Brown KW. (2014). The benefits of being present: mindfulness and its role in psychological wellbeing. Journal of personality and social psychology, 84(4), 822.

DeJong H, Fox E, Stein A. (2016). Rumination and postnatal depression: A systematic review and a cognitive model. Behaviour research and therapy, 82:38-49.

Douven E, Staals J, Schievink SH, Van Oostenbrugge RJ, Verhey FR, Wetzels-Meertens S. (2018). Personality traits and course of symptoms of depression and apathy after stroke: Results of

$$
\begin{aligned}
& \text { ارائه ندهد؛ بنابراين، بهتر است در يثروهشهاى آتى از } \\
& \text { روشهاى تركيبى جهت گردآورى داده ها استفاده شود. } \\
& \text { علاوه بر اين نتايج حاصل اين ئزوهش حاصل مطالعهى }
\end{aligned}
$$

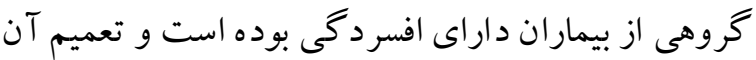

$$
\begin{aligned}
& \text { به ساير بيماران، نيازمند بثزوهش در همان موقعيتها است. } \\
& \text { با توجه به نتايج به دست آمده از ئزوهش بيشنهاد مى شود }
\end{aligned}
$$

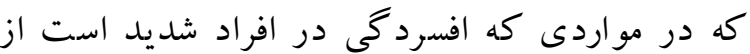

$$
\begin{aligned}
& \text { درمان متمر كز بر شفقت به خود و بركز ارى كار گاههاى } \\
& \text { آموزشى جهت مديريت نشخوار فكرى استفاده شود. } \\
& \text { همجنين بيشنهاد مى شود اين بُزوهش در مناطق ديخر } \\
& \text { كشور هم انجام و نتايج آن با برزو هش حاضر مقايسه شود. } \\
& \text { همجنين ساير متغيرهاى روانشناختى تأثير گذار بر } \\
& \text { افسردگى را مو رد مطالعه و بررسى قرار دهند. } \\
& \text { سياسگز ارى } \\
& \text { به منظور رعايت موازين اخلاقى، شركت كنند } \\
& \text { شرايط يزٔوهش آكاه شدند و از آنها رضايت آكاهانه و }
\end{aligned}
$$

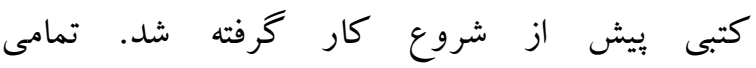

$$
\begin{aligned}
& \text { شر كت كنند كان در ئزوهش بعد از اجراى طرح به منظور } \\
& \text { دريافت درمانهاى تكميلى به روان يزشك يا روانشناس، } \\
& \text { در صورت لزوم، ارجاع داده شدند. اين يزوهش، به تائيد } \\
& \text { كميته اخلاق دانشگاه علوم بزشكى ركرمانشاه } \\
& \text { (IR.KUMS.REC.1398.085) }
\end{aligned}
$$

\section{References}

Adamu AF, Adinew YM. (2018). Domestic Violence as a Risk Factor for Postpartum Depression Among Ethiopian Women: Facility Based Study. Clinical practice and epidemiology in mentalhealth:CP \& EMH, 14:109.

Agha Yousefi A, Kharboo A, Hatami H. (2014). The role of rumination in mental well-being and anxiety in the spouses of cancer patients in 
the CASPER study. JournalofPsychosomatic Research. 111.69-75.

Ferrari M, Yap K, Scott N, Einstein DA, Ciarrochi J. (2018). Self-compassion moderates the perfectionism and depression link in both adolescence and adulthood. PloS one, 13(2):e0192022.

Gilbert P, Irons C. (2008). Focused therapies and compassionate mind training for shame and self-attacking. Compassion: Conceptualizations, research and use in psychotherapy, 263-325.

Hoffmann SG, Grossman P, Hinton DE (2011). Loving-kindness and compassion meditation: Potential for psychological intervention. Clinical Psychology Review, 13, 1126-1132. doi:10.

Kapci EG, Uslu R, Turkcapar H, \& Karaoglan A. (2018). Beck Depression Inventory II: Evaluation of the psychometric properties and cut-off points in a Turkish adult population, Depression and Anxiety, 25, 104-110.

Krieger T, Altenstein D, Baettig I, Doerig N, Holtforth MG. (2013). Self-compassion in depression: Associations with depressive symptoms, rumination, and avoidance in depressed outpatients. Behavior therapy, 44(3), 13-50.

Krieger T, Berger T, Grosse Holtforth M. (2016). The relationship of self-compassion and depression: Cross-lagged panel analyses in depressed patients after outpatient therapy. Joumal of affective disorders, 39:45-202.

Lim VZ, Ho RC, Tee SI, Ho MS, Pan JY, Lim YL. (2016). Anxiety and depression in patients with atopic dermatitis in a Southeast Asian tertiary dermatological centre. Ann Acad Med Singapore, 45(10):451-5.

Luminet O. (2014). Measurement of depressive rumination and associated constructs. In Papageorgiou C, Wells A, editors. Depressive Rumination: Nature, Theory and Treatment. New York:Wiley \& Sons.

Mak A, Tang CS-K, Chan M-F, Cheak AA-C, Ho RC-M. (2011). Damage accrual, cumulative glucocorticoid dose and depression predict anxiety in patients with systemic lupus erythematosus. Clinical rheumatology, 30(6):795-803.

Momeni F, Shahidi S, Motaei F, Heidari M. (2013). Psychometric Properties of the Persian Version of the Self-Compassion Scale, Contemporary Psychology, Volume 8, Number 2, 40-27. (InPersian)

Moulds MC, Kandris E, Starr S, Wong ACM. (2007). The relationship between rumination, avoidance and depression in a non-clinical sample. Behaviour research and therapy, 45, 251-261.

NeffKD, DahmKA. (2015). Self-compassion: What it is, what it does, and how it relates to mindfulness Handbook of mindfulness and self-regulation. 121-137.

Neff KD, Pisitsungkagarn K, Hsieh Y. (2003). Selfcompassion and self-construal in the United States, Thailand, and Taiwan. Joumal of Cross-Cultural Psychology, 39(3), 267-285.

Neff KD. (2003). The development and validation of a scale to measure self-compassion. Self and identity, 2(3), 223-50.

Nezamipour E, Zarghami Haji M, Abdolmanafi A. (2014). The moderating role of problem solving methods in the relationship between rumination and depression in students, Clinical Psychology and Personality, 22(12), 15-24. (In Persian)

Nolen-Hoeksema S, Morrow J, Fredrickson BL. (1996). Response styles and the duration of episodes of depressed mood. Joumal of AbnormalPsychology, 102, 20-28.

Nolen-Hoeksema S, Morrow J. (1993). Effects of rumination and distraction on naturally occurring depressed mood. Cognition and Emotion, 7,561-570.

Nolen-Hoeksema S, Wisco BE, Lyubomirsky S. (2008). Rethinking Rumination. Perspectives on Psychological Science, 3(5), 400- 424.

Noorbala F, Borjali A, Noorbala A. (2013). The interactive effect of "self-compassion" and rumination of depressed patients in "compassion-based therapy", Daneshvar-eMadeshi, 20(104), 84 77.(InPersian) 
Papageorgiou C, Wells A. (2004). Depressive rumination: Nature, theory ,and treatment, New York: Wiley.

Rabon Kelliher J, Sirois FM, Hirsch JK. (2018). Selfcompassion and suicidal behavior in college students: Serial indirect effects via depression and wellness behaviors. Journal of American college health 66(2):114-22.

Raes F. (2010). Rumination and worry as mediators of the relationship between self-compassion and depression and anxiety. Personality and IndividualDifferences, 48(6):757-61.

Taylor MK, Beckerley SE, Henniger NE, Hemandez LM, Larson GE, Granger DA. (2017). A genetic risk factor for major depression and suicidal ideation is mitigated by physical activity. Psychiatry research, 249:3046.

Vos T, Allen C, Arora M, Barber RM, Bhutta ZA, Brown A, et al (2016). Global, regional, and national incidence, prevalence, and years lived with disability for 310 diseases and injuries: a systematic analysis for the Global Burden of Disease Study. The Lancet. 2016:388(10053):1545-602. 